\title{
Public Service Motivation Measurement: A Test of Perry's Scale in Indonesia
}

\author{
Hety Budiyanti \\ Faculty of Economics, Universitas Negeri Makassar \\ hety.budiyanti@unm.ac.id \\ Akhmat Yamin \\ Board of Human Resources Development, Central Sulawesi Province \\ yaminakhmat@gmail.com \\ Shine Pintor Siolemba Patiro \\ Board of Human Resources Development, Central Sulawesi Province \\ batikpakuan@gmail.com
}

\begin{abstract}
This article proposes and tests a shorter version of the instrument for public service motivation based on Perry's (1996) exploratory 24-item scale for Indonesia civil servants in five big cities, inter alia, Jakarta, Surabaya, Semarang, Makassar, and Medan. Of 1200 respondents, 904 completed the questionnaire, and 800 questionnaires were determined to be feasible for further analysis. Thus, the response rate was $88.50 \%$ the results indicated support for the shortened scale of Perry's original work on investigating the Public Service Motivation (PSM) of Indonesia civil servants in sample cities. The 10-item scale was based on four factors PSM, inter alia Attraction to Policy Making (APM), Commitment to the Public Interest (CPI), Compassion (COM), Self-Sacrifice (SS). Results also showed that, generally PSM for civil servant with basic positions in city government offices, in five cities tends to vary. The research results are expected to enhance our understanding about the importance of factors that influence the motivation of civil servants in providing public services to the general public. However, the limitation of the study lies in the small sample which is drawn from only five large cities in Indonesia.
\end{abstract}

Keywords: confirmatory factor analysis, indonesia civil servant, public service motivation, scale validation 


\section{INTRODUCTION}

The motivation of government employee constitutes one of the important issues in the theory and practice of public administration (Wright \& Pandey, 2008). Many scholars contend the need for government employees to be highly motivated to serve the general public, in comparison with private sector employees (Perry, 2014; Perry, Hondeghem, \& Wise, 2010; Perry \& Wise, 1990). Furthermore, many civil servants associate serving in public service with dedication to serve the nation, hence attach working for government a special status. To that end, there is an argument that employees who opt to serve their fellow citizens (public service) have certain and special attributes that may not be found in other employees (Perry, 1996).

Previous research support the above claims. This is especially true with respect to extrinsic rewards and outcomes that results sometimes vary by level of management and employee age (Brewer, Ritz, \& Vandenabeele, 2012). Whether referred to as public service ethic or motivation, the concept of PSM was coined by Perry \& Wise (1990) who defined the concept as "an individual's predisposition to respond to motives grounded primarily or uniquely in public institutions and organizations".

Perry \& Wise (1990) and Perry (1996) argue that individuals who are strongly motivated to do public service are supposed to work for public organizations, to perform better on the job, and to be more sensitive to intrinsic rewards. This is in line with Herzberg who notes that the motivational factor is intrinsic because it is associated with satisfaction an individual gets by performing on the work itself (Muskanan, 2015). Furthermore, Perry (1996) identifies a multidimensional scale to measure public service motivation (PSM), which comprises four components, inter alia, attraction to policy making (APM); commitment to public interest (CPI); compassion (COM); and self-sacrifice (SS). Using Perry's (1996) scale, a number of researchers have examined antecedents and effects of PSM (Camilleri, 2006; Castaing, 2006; Choi, 2004; DeHart-Davis, Marlowe, \& Pandey, 2006; Moynihan \& Pandey, 2007). Such studies have been con- ducted in the United States and other countries, and have led to substantial improvements in on the PSM scale as well as attracting more attention to PSM measurement that in turn has contributed to accumulation of knowledge about its antecedent and consequences (Bright, 2008; Camilleri, 2006; Castaing, 2006; Choi, 2004; DeHart-Davis et al., 2006; Lee, 2005; Moynihan \& Pandey, 2007; Pandey, Wright, \& Moynihan, 2008; Park \& Rainey, 2008; Perry, 1997; Perry, Brudney, Coursey, \& Littlepage, 2008; Steijn, 2008; taylor, 2008; Vandenabeele, 2008; Wright \& Pandey, 2008). However, there is yet no generalization of PSM dimensional structure and items. For example, Kim (2009) used a shorter scale of Perrry's instrument that comprises revised 12 items in the United States. However, there is still need for evidence on the application of the same instrument in other countries that may not share the same context as the United States. In some cases, some previous research excluded some dimensions from the analysis (Castaing, 2006; Coursey \& Pandey, 2007; DeHart-Davis et al., 2006; Moynihan \& Pandey, 2007; Wright \& Pandey, 2008); while other added new dimensions to the original instrument. An example of the latter, is Brewer, Selden, \& Face (2000) who found that there is not just one conception of PSM but four, inter alia, samaritans, communitarians, patriots, and humanitarians. Samaritans are highly motivated to help other people; communitarians are motivated by sentiments of civic duty and public service; patriots act out of benevolence and concern for the public; and humanitarians are motivated by a desire for social justice. Thus, primary motives common to all of these are serving the public, making a difference in society, and ensuring individual and social equity. Therefore, Brewer et al. (2000) argues that interest in politics and policy making is not a characteristic of any of the four conceptions of PSM.

Nonetheless, Vandenabeele et al. (2004) concludes that PSM is a universal concept and all the four dimensions of Perry (1996) can be verified using French and Dutch variants. In 2006, with the other colleagues, Vandenabeele et al. (2004) is describing the British and German variants with additions to PSM dimension came to 
the same conclusion. Choi (2004) used Perry (1996) scale in a study that examine the relationship between PSM and ethical behavior, concluded that only SS (do not use the abbreviation prior to stating what it stands for in full) in PSM is critical factor that influence ethical reasoning of public servants in the United States. When Perry's 24-item scale was applied to Korean public servants, Lee (2005) found that the APM component did not influence performance while the other three components did.

Camilleri (2006), in a study that used Perry's (1996) 24-item scale on 2,135 Maltese public officials, showed that organizational commitment strengthens PSM, while affective commitment has a direct effect on all the dimensions of PSM. Black, Jang, \& Kim (2006) examined whether the structure of PSM observed by Perry (1996) can be generalized to the setting in Korea. He found that although the four-factor structure of PSM can be generalized to the Korean context, there is still doubt as to whether APM in the second-order model is a valid dimension of PSM in Korea due to its very low standardized factor loadings. Meanwhile, Moynihan \& Pandey (2007) showed that PSM has strong and positive relationship with education attainment, membership in professional organizations, hierarchical authority, and reform efforts. On the contrary, red tape and length of organizational membership were found to have negative relationship with PSM.

In light of the inconsistency that is apparent in previous research on antecedents and effect of PSM, this study focused on the dimensions of PSM items in Perry's (1996) scale. To that end, the main purpose of this research is to determine whether items that measure PSM in Perry (1996) instrument are appropriate if implemented in different country context from that where tested his instrument. Moreover, Perry's (1996) original items to measure the APM dimension have been the subject to considerable controversy as to their relevance. In a research conducted by Kim (2009), results showed that the original items of PSM have little face validity as indicators of APM itself or of rational motivation because some of the items are not asking whether respondents are attracted to public policy making, rather whether they like or dislike politics, politicians and political phenomena. In line with Kim (2009), Coursey \& Pandey (2007) argue that in the original instrument, the terms politics and politicians arouse negative reactions and political distrust. This makes the addition, development, and testing of new items important in the APM dimension. As Perry (1996) himself acknowledged, the original subscale, comprises entirely negatively worded items, hence has the likelihood of confounding whether the subscale taps the attraction of respondents to policymaking dimension or cynicism or negative affect toward politics. Such criticism made revision of the original measurement scale necessary.

In s study by Kim (2009), he developed new items to measure APM, and subsequently tested a revised 12-item PSM scale. However, there is still need for additional testing and evaluation using samples from different settings. Thus, this study tried to test the validity of Perry (1996)'s PSM items using with a different sample from that used in the original study. Specifically, this study analyzes and tests Perry(1996)'s scale in the Indonesian context by investigating PSM of civil servants in five big cities of Indonesia, namely, Jakarta, Surabaya, Semarang, Makassar, and Medan. Although many studies conducted in the United States and in other countries have adopted Perry's (1996) scale, dimensions and items the measurement scale of PSM has not been thoroughly examined in Indonesia's context. Previous research by Camilleri (2006), Castaing (2006), Choi (2004), DeHart-Davis, Marlowe, \& Pandey (2006), Moynihan \& Pandey (2007) showed that the Perry's PSM concept is appropriate to organizations that are characterized by individualism which is the case in western countries. To that end, there are still doubts as to whether Perry (1996) instrument can have the same results in organizations that have collectivism cultural characteristics such is the case in eastern countries.. Besides, PSM measurement in Indonesia has by and large, been based on the general concept such as motivation scale, which was developed by Herzberg, Maslow or McClleland. Consequently, as Braender and Andersen (2013) argues, using Perry's scale to measure PSM in Indonesia has the tendency of 
Table 1. Background of Respondents $(n=800)$

\begin{tabular}{lcc}
\hline Variables & Characteristics & Respondents (\%) \\
\hline \multirow{2}{*}{ Sex } & Male & 65 \\
& Female & 35 \\
Age & $30 \mathrm{~s}$ & 38.3 \\
& $40 \mathrm{~s}$ & 36.6 \\
Education & Bachelor degree & 37.5 \\
& Master & 31.25 \\
Length of service & Doctoral & 31.25 \\
(years) & 10-20 & 52.9 \\
& More than 20 & 23.3 \\
Organization & Provincial Headquarters & 50 \\
& Provincial Human Resources Development & 25 \\
& Agency & 25 \\
\hline
\end{tabular}

Source: Data Analysis

generating higher motivation score for public sector employees compared with their private sector. To that end, there need to conduct an empirical examination of the four components of PSM in the Indonesians context.

Moynihan, Vandenabeele \& BlomHansen (2013) argues that work motivation can be regarded as energy of an individual who's willing to invest in his/her job. In addition, Moynihan, Vandenabeele \& BlomHansen (2013) stresses the importance of distinguishing between motivation as the energy or fuel behind actions and values as conceptions of what is desirable that direct behaviors towards certain end states. Moreover, it is important to recognize that motivation is a complex construct that can take a number of forms that originate from different sources (Perry, 1996). According to Perry \& Wise (1990) and Perry (1996), motivation that is fueled primarily by the desire to obtain benefit by oneself is different from that fueled by the desire to do good for others, defining the latter as prosocial motivation. Prosocial motivation is evident in day to day life of Indonesians, for example, in the event of a natural disaster when people all sections of society and walks of life will- ingly donate and provide assistance those affected by natural disaster (Mirza, 2008). Besides, another example of high prosocial motivation is illustrated by the action of the Indonesian government. Whenever an economic crisis occurs the government immediately takes various measures and policies to mitigate its impact on the welfare of the population by providing social and economic protection crisis (Katiman, 2012).

Perry and Wise (1990) contends that a public service motivation (PSM) constitutes a type of prosocial motivation that not only prevails in the context of public service delivery but also can help to predict behavior and performance of people involved in providing public services Rainey (1982) was the first to introduce the concept of public service motivation (PSM), which Perry \& Wise (1990) formalized later, which led to the first conceptualization y of the definition and identifying of typology of motives associated with public service. Motives identified consist of rational, norm-based, and affective motives. Subsequently, Perry (1996) developed a measurement scale, which empirically reduced the typology of motives to four dimensions, inter alia, attraction to public policy making, commitment to public in- 
Hety Budiyanti, Akhmat Yamin, Shine Pintor Siolemba Patiro - Public Service Motivation Measurement....

Table 2. Socially Desirable Response Statistic

\begin{tabular}{ll}
\hline \multicolumn{1}{c}{ Factors and Items } & p value \\
\hline \begin{tabular}{l}
\multicolumn{1}{c}{ Attraction to policy making } \\
PSM1: I am interested in making public programs that are beneficial for my
\end{tabular} & 0.187 \\
country or the community I belong to. & 0.146 \\
PSM2: Sharing my views on public policies with others is attractive to me. & 0.871 \\
PSM3: Seeing people get benefits from the public program I have been deep- \\
ly involved in brings me a great deal of satisfaction. \\
$\begin{array}{l}\text { PSM4: I consider public service my civic duty. } \\
\text { PSM5: Meaningful public service is very important to me. }\end{array}$ \\
$\begin{array}{l}\text { PSM6: I would prefer seeing public officials do what is best for the whole } \\
\text { community even if it harmed my interests. }\end{array}$ \\
$\begin{array}{l}\text { PSM7: It is difficult for me to contain my feelings when I see people in dis- } \\
\text { tress. }\end{array}$ \\
$\begin{array}{l}\text { PSM8: I am often reminded by daily events how dependent we are on one } \\
\text { another. }\end{array}$ \\
$\begin{array}{l}\text { PSM9: I feel sympathetic to the plight of the underprivileged. } \\
\text { PSM10: To me, patriotism includes seeing to the welfare of others. }\end{array}$ \\
$\quad$ Self-Sacrifice \\
$\begin{array}{l}\text { PSM11: Serving other citizens would give me a good feeling even if no one } \\
\text { pay me for it. }\end{array}$
\end{tabular}

Source: Data Analysis

terest and civic duty, compassion, and selfsacrifice. The PSM concept itself, has been associated with public performance improvement and public value creation (Perry et al., 2010), which in turn has led to an increase in the popularity of the measurement scale (Perry \& Hondeghem, 2008; Vandenabeele, Ritz, \& Brewer, 2014).

Wise (2000) argues that PSM is associated with people's behavior motives. In the same vein, Perry and Wise (1990) define PSM "an individual's predisposition to respond to motives grounded primarily or uniquely in public organization institutions. In line with Perry and Wise (1990), Brewer \& Selden (1998) and Brewer et al. (2012) define PSM as "the motivational force that induces individuals to perform meaningful public service." Meanwhile, Moynihan et al. (2013) defines PSM as "a general altruistic motivation to serve the interests of a community of people, a state, a nation or mankind." Vandenabeele (2007) defines the concept as "belief, values and attitudes that go beyond self-interest or organizational interest, that concern the interest of a larger political entity and that motivate individuals to act accordingly whenever appropriate." In yet another definition, Vandenabeele (2007), Perry \& Hondeghem (2008), describe the concept as "an individual's orientation to deliver services to people with a purpose to do good for others and society." Nonetheless, there is commonality among different 
Table 3. Descriptive Statistics

\begin{tabular}{lccc}
\hline \multicolumn{1}{c}{ Item } & Mean & Standard Deviation & Item-Total Correlation \\
\hline PSM1 & 3.3219 & 1.20139 & .806 \\
PSM2 & 3.3097 & 1.18932 & .849 \\
PSM3 & 3.0553 & 1.18464 & .480 \\
PSM4 & 3.8020 & .93271 & .466 \\
PSM5 & 4.1173 & .71495 & .437 \\
PSM6 & 3.8805 & .92168 & .497 \\
PSM7 & 3.3363 & 1.10859 & .735 \\
PSM8 & 3.4646 & 1.19841 & .745 \\
PSM9 & 3.6217 & 1.11499 & .536 \\
PSM10 & 2.8684 & 1.17247 & .202 \\
PSM11 & 2.9569 & 1.10737 & .625 \\
PSM12 & 2.6936 & 1.17661 & .246 \\
PSM13 & 2.5498 & 1.19882 & .735 \\
PSM14 & 2.6449 & 1.07370 & .703 \\
& $\mathrm{~N}=800$ & & \\
\hline
\end{tabular}

Source: Data Analysis

definitions, which is the focus on motives and action that are driven by the desire to do good for others with the purpose of contributing to the wellbeing of society..

Previous research on PSM of government employees, inter alia, Perry et al. (2010), Moynihan et al. (2013), Perry (2014), and Vandenabeele \& van loon (2015) established the fact that Public sector employees do not only attach high value to helping others, serving society and the public interest, and performing work that is worthwhile to society, but also rank high on appreciation of intrinsic rewards as source of motivation to work than private sector employees. Perry et al. (2010) found that public -sector employees rate job characteristics that arouse the feeling of accomplishment and performing helpful work for society as important compared to the perception of private-sector employees for similar work and performance. In the same vein, Skelcher \& Smith (2015) noted the existence of a significant relationship between PSM on one hand, and job satisfaction, performance, in- tention to remain in the government, and support for the government's reinvention efforts for federal employees. To corroborate the same finding, Moynihan et al (2013) found that PSM is a predominant factor behind public sector behavior and performance. This is attributable to the importance and value public employees attach to intrinsic reward for work performance and sense of accomplishment.

Besides, prior to the work by Moynihan et al (2013) in another research on PSM that tested the comprehensive PSM model, Giauque, D et. al. (2009), established that PSM was a modestly important predictor of organizational performance In other words, the higher the level of PSM , the higher the performance of government employees. Meanwhile, Brewer et al. (2012) showed that public employees score higher on attitudinal items related to social trust, altruism, equality, tolerance, and humanitarianism and more civil engaged as reflected in their ability to perform more than one-third more civic activities than other citizens. In several 


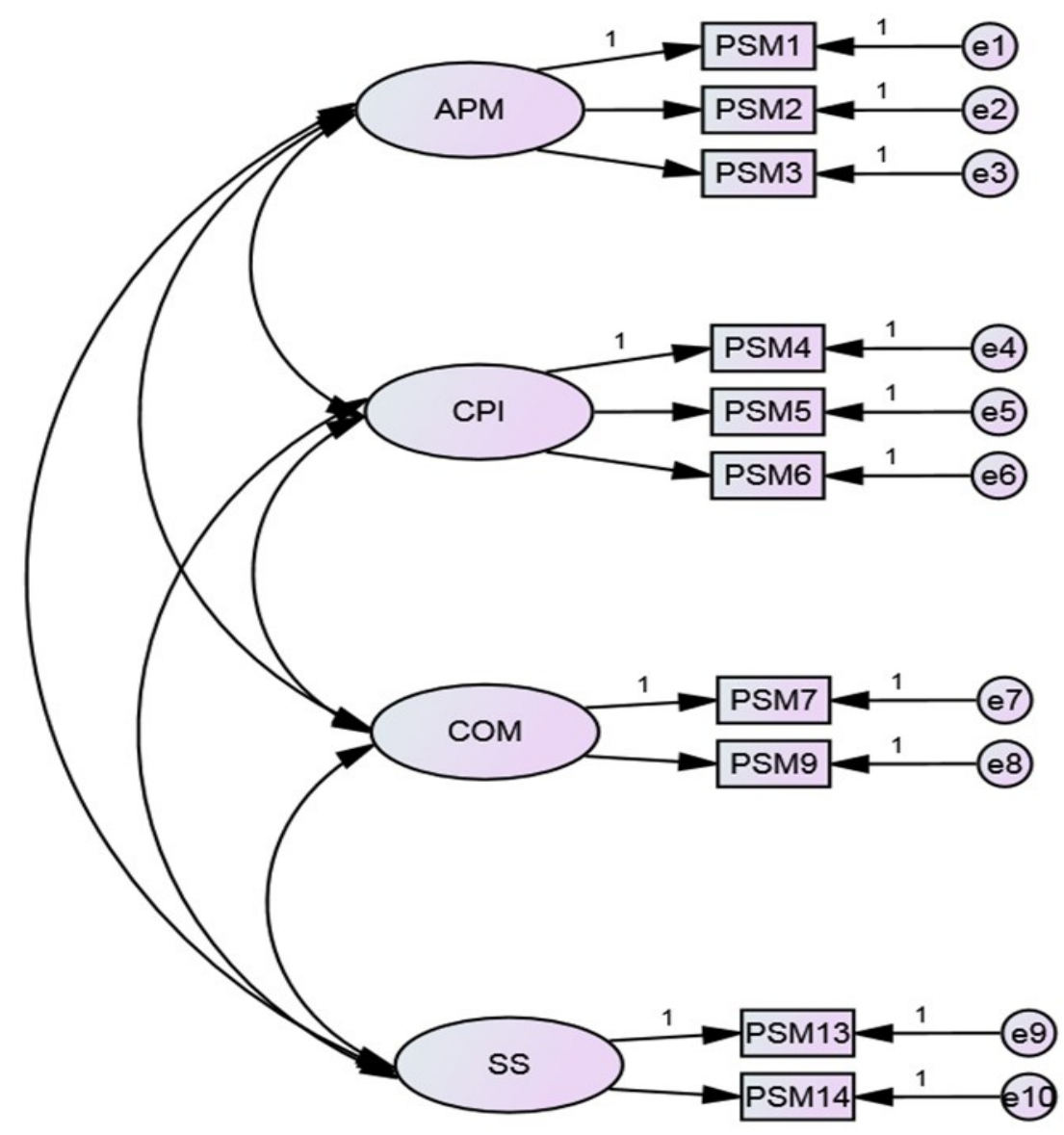

Figure 1. Final Confirmatory Factor Analysis Model for Public Service Motivation in Indonesia Source: Data Analysis

cases in Korean, Lee (2005) found with respect to PSM the performance of public servants showed a statistically significant difference from that of , and that high PSM was associated with high performance. In line with Lee (2005), Perry \& Hondeghem (2008) found that PSM had a positive relationship with the multidimensional measure of organizational performance and organizational citizenship behavior. Based on 2002 General Social Survey data, which Houston (2006) used to conduct research on PSM among public sector and private sector employees, results showed that there was higher likelihood for government employees to vol- unteer for charity and to donate blood than employees of for-profit organizations. In addition, like previous research, Houston also found that PSM was more prominent in the public sector than in private sector organizations.

\section{METHODS}

Perry (1996) developed an instrument that contains a list of 24 items for four dimensions of PSM. Kim (2009) later reduced the scale to 14 items and confirmed that the four factor structure of PSM can be generalized to the Korean context. This study is based on the-14 item PSM scale, which was 
Table 4. Maximum Likelihood Estimates for Four-Dimensional Model

\begin{tabular}{lccc}
\hline Coefficients & $\begin{array}{l}\text { Standardized ML Estimates } \\
\text { (Standard Errors) }\end{array}$ & t-values & $\mathbf{R}^{2}$ \\
\hline Attraction to Policy Making & $.703(.05)$ & 14.06 & .494 \\
PSM1 & $.981(.102)$ & 9.618 & .563 \\
PSM2 & $.682(.051)$ & 13.372 & .233 \\
PSM3 & & & \\
Commitment to The Public Interest & $.630(.05)$ & 12.60 & .397 \\
PSM4 & $.609(.085)$ & 7.164 & .260 \\
PSM5 & $.603(.137)$ & 4.401 & .364 \\
PSM6 & & & .105 \\
Compassion & $.684(.05)$ & 13.68 & .211 \\
PSM7 & $.607(.048)$ & 12.65 & \\
PSM9 & & & .185 \\
Self-Sacrifice & $.620(.05)$ & 12.40 & .285 \\
PSM13 & $.644(.040)$ & 16.10 & \\
PSM14 & & & \\
\hline
\end{tabular}

Source: Data Analysis

developed by Kim (2009), and is a modification of Perry (1996) instrument by There were several design considerations in testing the PSM scale in this research. Construct validity, which measures the suitability and appropriateness of conceptual and operational definitions of public service motivation (Schwab, 1980); the unidimensionality of component constructs that comprise the scale (Anderson \& Gerbing, 1988); and parsimony. As noted by MacKenzie, Podsakoff, \& Jarvis (2005) the more concise the measurement instrument, the more easily and frequently it can be used. All the scales are based on a 5-point Likert-type scale (1 = strong disagreement; $5=$ strong agreement). To gauge the equivalence of the measures to Indonesian versions, all the scales used in this study had to be translated into bahasa Indonesia. Meanwhile to enhance accuracy of responses, the distribution of every questionnaire was accompanied by a cover sheet that guaranteed anonymity of the results. Thus, this study used 14 positively worded items to measure PSM that comprised 3 items for the APM, 3 items for CPI, 4 items for COM, and 4 for SS dimensions.

There is however, contention over the use of APM in measuring PSM. According to $\operatorname{Kim}(2009 ; 2010)$, the rational motive might not be related to PSM in the Asian context. Furthermore, Kim continues his argument, that the rational motive itself is not part of PSM. So, items of APM might not be appropriate to represent the rationality underlying PSM, which is compounded by the use of negatively worded items that are deemed not appropriate to assess APM. In light of such misgivings, this used Perry's measurement scale but is only limited to revise items that are positively worded, hence considered more appropriate to represent APM, CPI, COM, and SS dimensions.

\section{Public Service Motivation (PSM) Dimen- sions and Measures}

Previous research over the last decade has generated multiple definitions of the PSM concept which on varied ways and context capture its essence (Brewer \& Selden, 1998; Perry \& Wise, 1990; Rainey \& Steinbauer, 1999; Vandenabeele, 2007). Perry et 
Hety Budiyanti, Akhmat Yamin, Shine Pintor Siolemba Patiro - Public Service Motivation Measurement....

Table 5. Correlation of Dimensions

\begin{tabular}{ccccc}
\hline & & & Estimate \\
\hline COM & $<-->$ & SS & .218 \\
CPI & $<-->$ & COM & .239 \\
APM & $<-->$ & CPI & .306 \\
CPI & $<-->$ & SS & .104 \\
APM & $<-->$ & SS & .240 \\
APM & $<-->$ & COM & .205 \\
\hline
\end{tabular}

Source: Data Analysis

al. (2010) defines PSM as "an individual's orientation to delivering services to people with purpose to do good for others and society". In that respect, the above definition is useful for several reasons. First, the definition does not associate PSM with a particular sector (contrary to original definitions (Perry and Wise, 1990), which is very relevant because public service may be a powerful motivator in public, non-profit as well as for-profit organizations (Perry, 2014). Secondly, the definition emphasizes the core purpose of this type of motivation, which is to do good for others and society.

According to Perry (1996), PSM consists of four components, inter alia, "commitment to the public interest", "compassion", "attraction to policymaking" and "self-sacrifice". The latter represents fundamental willingness to substitute service to others and society for personal pecuniary rewards. In an elucidation of one of components of PSM, Kim (2011) argues that, selfsacrifice is closely tied to the altruistic foundations of other dimensions. It is surprising therefore that Braender \& Andersen (2013) concurs with Kim's statement by noting self -sacrifice as constitutes "pure fuel behind prosocial actions". The other three components of PSM are based on norm-based, affective, and instrumental motives for engaging in public service behaviors, respectively (Perry and Wise, 1990). Norm-based motives are driven by the desire and sense of duty and obligation to serve society (Perry and Wise, 1990). Meanwhile, affective motives are related to the motivation that is linked to emotional identification with specific groups. Indeed, research on empathy consistently emphasizes perceived welfare of other people as a powerful motivator (Perry and Wise, 1990). Finally, Kjeldsen (2012) argues that instrumental or rational motives represent motivation that is aimed at improving welfare for the largest population possible through participation in decisionmaking processes.

Kim \& Vandenabeele (2010) contend that PSM dimensions are distinct hence can have different antecedents and consequences. The instrument Perry (1996) developed to measure PSM, Comprised 40 survey items, which represent six dimensions of PSM, inter alia, Attraction to Policy Making APM); Commitment to the Public Interest (CPI); Civic Duty; Social Justice' Compassion (COM); and Self Sacrifice (SS). To test the instrument, Perry (1996) used data from a survey of 376 respondents who were drawn from a variety of primarily public sector backgrounds. Results led Perry (1996) to identify four empirical components of the PSM construct that consist of APM, COM, CPI, and SS.

Four of the four subscales map directly to the motivational foundation (Perry, 1996, 2000). APM represents rational choice processes, hence can be used to reinforce an 
Table 6. Variance of Errors

\begin{tabular}{lccccc}
\hline & Estimate & S.E. & C.R. & P & Label \\
\hline APM & .708 & .078 & 9.129 & $* * *$ & par_13 \\
CPI & .345 & .061 & 5.655 & $* * *$ & par_14 \\
COM & .800 & .302 & 2.650 & .006 & par_15 \\
SS & .265 & .049 & 5.408 & $* * *$ & par_16 \\
e1 & .725 & .059 & 12.239 & $* * *$ & par_17 \\
e2 & .450 & .087 & 5.172 & $* * *$ & par_18 \\
e3 & 1.065 & .057 & 18.519 & $* * *$ & par_19 \\
e4 & .524 & .057 & 9.265 & $* * *$ & par_20 \\
e5 & .374 & .025 & 14.857 & $* * *$ & par_21 \\
e6 & .542 & .050 & 10.919 & $* * *$ & par_22 \\
e7 & .566 & .104 & 5.442 & $* * *$ & par_23 \\
e8 & 1.231 & .067 & 18.284 & $* * *$ & par_24 \\
e9 & 1.172 & .154 & 7.602 & $* * *$ & par_25 \\
e10 & 1.255 & .296 & 4.240 & $* * *$ & par_26 \\
\hline Source: Data & Analys & & & &
\end{tabular}

Source: Data Analysis

individual's image of self-importance. This motive is considered unique to public institutions. Meanwhile, according to Kelman (1987) , "a rational motive that some argue draws individuals to public service is the opportunity to participate in the formulation of public policy." CPI coincides with normative processes. Perry (1996) describes commitment to the public interest as "one of the most commonly identified normative foundations for public service". In line with Perry (1996), Downs (1967) argues "that the desire to serve public interest is essentially altruistic even when the public interest is conceived as an individual's opinion." COM represents affective processes. Concerning this subscale, Frederickson \& Hart (1985) suggest that the central motive for civil servants should be "patriotism of benevolence, " what is termed here compassion. Furthermore, they define patriotism of benevolence as "an extensive love of all people within our political boundaries and the imperative that they must be protected in all of the basic rights granted to them by the enabling documents." SS is the last subscale, which according to Perry (1996), embodies "the will- ingness to substitute service to others for tangible personal rewards."

Thus, Perry's study culminated into the development of a list of 24 items measuring that measure the four subscales of PSM. Subsequently, PSM components, have been subjected to further analysis. Perry (1997) investigated several antecedents of PSM with the same dimensions of his 1996 study, and reached the conclusion that an individual's PSM is aroused by the exposure to a variety of experiences, some associated with childhood, some associated with religion, and some associated with professional life. That said, the 24-item multidimensional scale of PSM has not been fully examined in various country or sub-regional contexts. Using Perry's items as a backdrop, Kim (2009) developed a 14-item scale that comprises four factors, including, APM, CPI, COM, and SS.

\section{Samples}

The data for this study were collected from 800 civil servants occupying various echelons in various government city offices in some of Indonesia's big cities, namely: 
Jakarta, Surabaya, Semarang, Makassar, and Medan. These cities were chosen as samples because they are big cities in Indonesian populous regions. The field survey was conducted in August 2017. The research team had to provide a comprehensive and informative explanation about the purpose of the study to head officers who latter provided a lot of help to the research team in distributing and collecting the questionnaires. The survey was administered to all permanent civil servants $(1,200)$ in the sample city governments and were supposed to be completed during working hours. In all 904 questionnaires were returned, which represented a response rate of $75.33 \%$. Data that were used for analysis eliminated 104 cases that had missing data in any or PSM indicators. Finally, 800 cases which were completely filled out formed the final sample. Of the 800 respondents, $65 \%$ were male, and 35 5 female With respect to the educational background of respondents, $37.5 \%$ had at least a bachelor's degree; $31.25 \%$ had a master's and doctorate degree. By age, $38.3 \%$ were in their $30 \mathrm{~s}$; followed by those who fell into $40 \mathrm{~s}(36.6 \%)$ hence formed the largest sub group. As regards working experience, more than half $(52.9 \%)$ of respondents had worked for more than 10 years but less than 20 years in the civil service; while $23.3 \%$ had worked for at least 20 years and above. As regards, place of work, $50 \%$ worked at the Provincial government headquarters; $25 \%$ served in the provincial human resources development agency; and $25 \%$ of respondents were employees in the provincial personnel agency. Table 1 shows a complete background of respondents.

\section{FINDINGS AND DISCUSSION}

\section{Socially Desirable Response Test}

Prior to conducting the first survey, we carried out a socially desirable response (SDR) on civil servants located in Yogyakarta city. The purpose of the test was to gauge the extent to which survey instrument was susceptible to bias, which is associated with self-report (Fisher, 1993), which Perry (1996) didn't conduct. The bias is significant, yet is often overlooked by researchers (Fisher, 2000). Thus, in this study, the SDR test was done by giving indirect questions to respondents, and subsequently comparing responses with those that are given to direct questions (non-paired sample). The SDR test involved 60 respondents, 50 percent of whom were required to fill out the questionnaire with direct questions and the other half were given questionnaires with indirect questions. Responses to SDR test were subjected to Mann-Whitney test, and construct validity and reliability tests, to determine the suitability of indicators used. Results of the tests appear in Table 2. Results of the SDR test for non-paired sample showed that the $p$ value was above 0.05 , which implies that the mean of the two samples was not statistically different In other words, the average respondent answer would be the same in both cases.

\section{Analyses}

The maximum likelihood estimation method was used to conduct Confirmatory factor analysis (CFA). CFA is used to assess the extent to which data fits the hypothesized measurement model. Several descriptive fit indices are used to assess model fit, including CMIN/DF, goodness of fit index (GFI), adjusted goodness of fit index (AGFI), comparative fit index (CFI) incremental fit index (IFI), and the root mean square error of approximation (RMSEA). Bollen (1989) stated that although there are no specific guidelines for assessing model fit, in general, the larger CFI and IFI values, and the smaller the RMSEA value, the better the model (Bollen, 1989). The model achieves an acceptable fit to the data when GFI, AGFI, CFI, and IFI equal or exceed 0.90 and RMSEA values fall below 0.08 (Byrne, 2001; Kline, 2005).

Descriptive and reliability statistics were computed for individual items and the 14-item scale. The descriptive statistics are presented in Table 3. Based on the results, two items (PSM 10, 12) were dropped from the model because of low variances and being weakly correlated with the overall scale. The item-total correlations for these items ranged from 0.202 to 0.246 , which well below the average for other items. Thus, next analysis stage used 12 items.

\section{Confirmatory Factor Analysis}

The scale construction problem addressed in the present study is well suited to 
CFA (Bollen, 1989; Diamantopoulos \& Siguaw, 2006), as it permits specification and testing of a more complete measurement model. Considering the common problem that the initial measurement models often fails to provide acceptable fit, based on previous research, this study conducted CFA in two stages (Anderson \& Gerbing, 1988). According to Joreskog (1993), the first stage is strictly confirmatory and it involves testing whether the four-dimension, twelve-variable model would be accepted or rejected. The second model is generated based on results obtained in the first stage; that is the confirmatory factor analysis in the initial model. If the initial model is rejected, then the model may be modified and tested again using the same data.

The initial CFA model in this study had the following specification: (1) four dimensions, corresponding to the theoretical model of public service motivation, with each dimension or factor correlated with the other dimensions; (2) twelve observed variables, each loading on only one latent dimension or factor as indicated in Table 3 by excluding PSM 10 and PSM 12; and (3) uncorrelated error terms. Model identification is in accordance with Bollen's (1989) identification rules for CFA. Accordingly, the chisquare statistic for the model should be 274.317, with degrees of freedom 48 ( $p=$ 0.00 ), which would suggest poor model fit. To provide alternative perspective on model fit, several alternative goodness of fit measures can be used, including CMIN/DF, GFI, AGFI, CFI, and RMSEA. The result of the model used in the research was as follows; the value of goodness of fit index (GFI) was 0.946; the adjusted goodness of fit index (AGI) was 0.913; comparative fit index (CFI) was 0.921 . The 0.90 benchmark is typically to determine whether or not model fit tests in acceptable. The root mean square error (RMSEA) was 0.074, which being below the recommended threshold indicated good model fit. Nonetheless, CMIN/ DF had a value of 5.72 , which indicated moderate fit.

Based on the result of initial model, an effort was made to estimate an alternative model. Variables which had loading factor that fellow below the 0.60 value, were eliminated one at a time, which was aimed at strengthening the unidimensionality of the factors. Consequently, two variables were eliminated (PSM 8 and PSM 11) in the first two iterations because the loading factors showed loadings that were below 0.60 .

After the overall number of indicators had been reduced to ten, the estimation of the second model generated ten indicators in four dimensions. The final adjustments to the model resulted into four dimensions and observed variables as depicted in Figure 1. The result of the second model goodness of fit index (GFI) was 0.965 , while the adjusted goodness of fit index (AGI) was 0.933 , the comparative fit index (CFI) was s 0.927 (above the 0.90 benchmark used to determine acceptability). The root mean square error (RMSEA), and CMIN/DF registered 0.070 and 3.47 values, respectively, which proved good fit.

Table 4 shows results of validity and reliability results of the PSM scale t-values of the parameter estimates reported in Table 4 are significant at the 0.001 and 0.05 significance levels ( 99 percent and 95 percent confidence levels, respectively). Factor loadings range from 0.603 to 0.981 . The coefficients may be interpreted as indicators of the validity of the observed variables, which attests the degree to which observed variables represent latent dimensions or factors. Given the level of significance of the estimates and the magnitude of the coefficients, observed variables or indicators were determined to be valid measures of the dimensions. The $\mathrm{R}^{2}$ in Table 4, which is a measure of the reliability, indicates degree of consistence at which observed variables measure up to latent dimensions. The $\mathrm{R}^{2} \mathrm{~s}$ range from 0.105 to 0.563 , suggesting that the reliability of factor loadings varies significantly.

Coefficient alpha is the traditional measure of instrument of measuring scale reliability, gauges the internal consistency among items on a scale. Coefficient alpha for the ten-item PSM scale should be 0.90, which value however, is at the upper end of the range for acceptable internal consistency. Coefficient alphas for the four subscales ranged from 0.601 to 0.763 , which therefore serve as independent corroboration of the results obtained from confirmatory factor analysis. Table 5 shows correlation analysis 
results between APM, CPI, COM, and SS constructs. Table 6 shows that not all the variance in each scale co-vary with the latent factors. In other words, measures of latent factors used in this passed the adequacy test. In other words, data sample is suitable to the hypothesized model.

The purpose of this study was to confirm whether dimensions in Perry (1996) measurement scale are valid measures for Indonesian civil servants. Kim's study, found that the initial model with Perry (1996) that comprised 24 items was not a good fit to the data, which led to the development of a modified instrument that consists of 14-items that represent four factors. That said, doubt about relevancy of Compassion (COM) and Self Sacrifice (SS) dimensions in the PSM model remained. This study used a 14-item scale based on Perry (1996) scale construction. Study results showed that the four-factor structure of Perry's PSM with 14-items scale can be generalized into four-factor structure but with 10item scale in the Indonesian context. Therefore, the contribution of this model to Perry (1996) model is that while four construct model is relevant to the Indonesian context, items that are used to measure the four dimensions are reduced to 10 (from the original 14 items). To that end, study results represent the modification of Perry (1996) measuring scale of PSM that is appropriate for the context of Indonesian civil service.

As an example, this study removed item 8 (I am often reminded by daily events how dependent we are on one another) and item 10 (to me, patriotism includes seeing to the welfare of others) from the COM dimension because of its loading factor. The justification for the removal of item 8 may be found in the nature of Indonesian people who consider interdependence between people as not simply driven by intrinsic motives but individual interest (Laksamana, 2002). As for the meaning of item on patriotism, Indonesians express patriotism through (1) the attitude of love for the homeland and nation; (2) willingness to sacrifice for the benefit of the nation and state; (3) the attitude of placing unity and national salvation above personal and group interests; and (4) the attitude of promoting and furthering unity and diversity which is encapsulated in the national motto of Bhinneka Tunggal Ika (Rianto \& Firmansyah, 2017). To that end, Indonesians attach different meaning to patriotism as represented in item 10 of the COM dimension.

Meanwhile, item 11 (Serving other citizens would give me a good feeling even if no one paid me for it) and item 12 (Making a difference in society means more to me than personal achievements) in the SS dimension were excluded as well. This was in part because of the low factor loading that was below 0.60 , which may indicate that Indonesian public servants provide service to others with the purpose of fulfilling selfinterest rather than serving selflessly interests of others (Prasetyaningsih, 2009). Thus, by prioritizing personal interests, providing public services is no longer driven by the need to help others but motivated by pursuit of individual achievements.

\section{CONCLUSION}

According to Perry \& Wise (1990) and Perry et al. (2010), what underlies motivation for public service delivery is an important issue in public administration. The purpose of this study was to determine the extent to which public service motivation (PSM) based on Perry's proposed scale, underpins the performance of public servants in Indonesia. Results of this study showed that data collected from civil servants drawn from various positions in five provinces confirmed the relevancy and validity of the a 10 - item PSM four-dimension scale as reflected in the good overall face and construct validity, reliability, and adequate discriminant validity.

Thus, the 10- item PSM scale can serve as a valuable a tool in accumulating empirical evidence about important facets of public administration especially drivers of motivation to serve. For example, the scale can be applied in assessing attitudinal changes among participants in President Jokowi's NawaCita program (One of the incumbent President's programs on reforming government administration and bureaucracy to enhance performance). Another possible application of the 10- item PSM scale is in both cross-sectional and longitudinal studies of 
bureaucratic reforms in other countries that have similar cultural characteristics to Indonesia. As has been mentioned in an earlier section of this study, the PSM scale can be applied in measuring differences in degree and magnitude of motivation of employees in government, business, and nonprofit organizations.

Results of this study provide sufficient evidence that the concept, dimension, and indicator of PSM in Perry (1996) model and its modification by $\mathrm{Kim}(2009)$ to a large extent captures the motivation of public sector employees in Indonesia. Thus, applying PSM appropriately and correctly, can be a very useful instrument in predicting the performance of public sector employees in Indonesia. Results of this study also provide an invaluable contribution to the development and enriching of the concept (construct) of PSM and its indicators, and dimensions. For example, in the context of Indonesia's civil servants, this study provided validation of the 10-item measurement scale from four dimensions, drawn from the 12-item scale as modified by Kim (2009), Based on results of this study, another implication is whether using the 12 measuring scale in other country contexts can lead to a reduction, maintain the original number of items, or even lead to an increase in the number of items that can capture all indicators of the four dimensions. This is an important area for future research.

An area for future research is the widening the sample of respondents to include as many cities as possible, represent different public servants that serve in various tasks and duties, and those in rural settings. Thus, studying PSM dimensions in the future is necessary to use this construct as formative indicators to provide more complete information.

In general this study has some limitations. This study employed a sample that was limited to five big cities in Indonesia, hence did not cover all the all cities in the 34 provinces of Indonesia. Moreover, respondents in study were civil servants, hence excludes employees in the private sector. To that end, results and implications of this study, cannot be generalized to civil servants in rural areas and the private sector in Indonesia.

\section{REFERENCES}

Anderson, J., \& Gerbing, D.(1988). Structural Equation Modeling in Practice: A Review and Recommended Two-Step Approach. Psychological Bulletin, 103(3), 411-423.

Black, B. S., Jang, H., \& Kim, W. (2006). Predicting firms' corporate governance choices: Evidence from Korea. Journal of Corporate Finance, 12(3), 660-691. https://doi.org/10.1016/ j.jcorpfin.2005.08.001

Bollen, K. . (1989). Structural Equations With Latent Variables. New York: wiley.

Braender, M., \& Andersen, L.(2013).Does Deployment to War Affect Public Service Motivation? A Panel Study of Soldiers Before and After Their Service in Afghanistan,. Public Administration Review, 73(3), 466-477.

Brewer, G., Ritz, A., \& Vandenabeele, W. (2012). Introduction to a symposium on public service motivation; an international sampling of research. International Journal of Public Administration, 35(1), 1-4.

Brewer, G., \& Selden, S.(1998). Whistle Blowers in the Federal Civil Service: New Evidence of the Public Service Ethic. Journal of Public Administration Research and Theory, 8(1), 413-439.

Brewer, G., Selden, S., \& Facer, R. L. I. (2000). Individual conceptions of public service motivation. Public Administration Review, 60(1), 254-264.

Bright, L. (2008). Does public service motivation really make a difference on the job satisfaction and turnover intentions of public employees? American Review of Public Administration, 38(1), 149-166.

Byrne, B.(2001). Structural equation modeling with Amos: Basic concepts, applications, and programming. (Mahwah, Ed.). NJ: Lawrence Erlbaum.

Camilleri, E. (2006). Towards developing an organizational commitment-Public service motivation model for Maltese public service employees. Public Policy and Administration, 21(1), 63-83.

Castaing, S.(2006). The effects of 
Hety Budiyanti, Akhmat Yamin, Shine Pintor Siolemba Patiro-Public Service Motivation Measurement....

psychological contract fulfillment and public service motivation on organizational commitment in the French civil service. Public Policy and Administration, 21(1), 84-98. https:// doi.org/10.1177/095207670602100106

Choi, D.(2004). Public service motivation and ethical conduct. International Review of Public Administration, 8(1), 99-106.

Coursey, D. H., \& Pandey, S.(2007). Public service motivation measurement: Testing an abridged version of Perry's proposed scale. Administration and Society, 39(1), 547-568.

DeHart-Davis, L., Marlowe, J., \& Pandey, S. (2006). Gender dimensions of public service motivation, "Public Administration Review. Public Administration Review, 66(1), 873-887.

Diamantopoulos, A., \& Siguaw, J.(2006). Formative versus reflective indicators in organizational measure development: A comparison and empirical illustration. British Journal of Management, 17(1), 263-282.

Downs, A. (1967). Inside Bureaucracy. boston: Brown.

Fisher, C. D. (2000). Mood and emotions while working: missing pieces of job satisfaction? Journal of Organizational Behavior, 21(2), 185-202.

Fisher, R.(1993). Social Desirability Bias and The Validity of Indirect Questioning. Journal of Consumer Research, 20(2), 303-315. https:// doi.org/10.1086/209351

Frederickson, H. G., \& Hart, D.(1985). The Public Service and the Patriotism of Benevolence. Public Administration Review, 45(1), 547-553.

Giauque, D, A., Ritz, A., Varone, F., Anderfuhren-Biget, S., \& Waldner, C. (2009). Motivation of public employees at the municipal level in Switzerland. In International Public Service Motivation Research Conference. bloomington:in.

Houston, D.(2006). Walking the walk" of public service motivation: Public employees and charitable gifts of time, blood, and money. Journal of Public Administration Research and Theory, 16(1), 67-86. https://doi.org/10.1093/ jopart/mui028

Joreskog, K. G.(1993). Testing Structural Equation Models. In Alternative ways of assessing model fit. (K. A. Boll, pp. 136-162). California: Sage publication.

Katiman (2012). The Role of Social Protection Program in Indonesian Economy: Its Origin And Development. Jurnal Kebijakan \& Administrasi Publik, 16(1), 21-38.

Kelman, S.(1987). "Public Choice" and Public Spirit. Public Interest, 87(1), 8094.

Kim, S.(2009). Revising Perry's

Measurement Scale of Public Service Motivation. The American Review of Public Administration, 39(2), 149-163. https:// doi.org/10.1177/0275074008317681

Kim, S.(2011). Testing a revised measure of public service motivation: Reflective versus formative specification. Journal of Public Administration Research and Theory, 21(3), 521-546. https:// doi.org/10.1093/jopart/muq048

Kim, S.,\& Vandenabeele, W.(2010). A Strategy for Building Public Service Motivation Research Internationally. Public Administration Review, 70(5), 701-709. https://doi.org/10.1111/j.1540 $-6210.2010 .02198 . \mathrm{x}$

Kjeldsen, A. M.(2012). Dynamics of public service motivation. Aarhus. Retrieved from http://forskningsbasen.deff.dk/ Share.external? $\mathrm{sp}=\mathrm{S} 8 \mathrm{ed} 5 \mathrm{cbc5}-5687$ 474e-9376-fa2f57df91 ba\&sp=Sau

Kline, R. B. (2005). Principles and practices of structural equation modeling ( $2 \mathrm{nd}$ ed.). New York: guildford.

Laksamana, A. (2002). The Effect of Interdependence, Trust, and Alignment Purpose Against Co-Operation and Performance Manufacturing Companies On Contractual Relation With Supplier. Accounting and Finance Jurnal, 4(1), 81-104.

Lee, G. (2005). PSM and public employees' work performance. Korean Society and Public Administration, 16(1), 81-104.

MacKenzie, S. B., Podsakoff, N. P., \& Jarvis, C. . (2005). The problem of measurement model misspecification in 
behavioral and organizational research and some recommended solutions. Journal of Applied Psychology, 90(4), 710-730.

Mirza, T.(2008). Efekttivitas Penyaluran Bantuan kemanusiaan Bagi Korban Bencana Pasca Tsunami di Banda Aceh. Jurnal Kebijakan \& Administrasi Publik, 12(1), 83-97.

Moynihan, D. P., \& Pandey, S.(2007). The role of organizations in fostering public service motivation. Public Administration Review, 67(1), 40-53. https://doi.org/10.1111/j.15406210.2006.00695.x

Moynihan, D. P., Vandenabeele, W., \& Blom-Hansen, J. (2013). Advancing public service motivation research. Public Money \& Management, 33(4), 288-289. https:// doi.org/10.1080/09540962.2013.79983 5

Muskanan, K. (2015). Analisis Motivasi Berprestasi Atlet Pusat Pendidikan dan Latihan Olahraga Pelajar ( PPLP) Provinsi Nusa Tenggara Timur. Jurnal Kebijakan \& Administrasi Publik, 19 (2), 105-113. Retrieved from http:// journal.ugm.ac.id/jkap

Pandey, S., Wright, B., \& Moynihan, D. P. (2008). Public service motivation and interpersonal citizenship behavior in public organizations: Testing a preliminary model,. International Public Management Journal, 11(1), 89-108. Retrieved from https:// doi.org/10.1080/10967490801887947\% 0A\%0APandey, S. K., Wright, B. E., Moynihan, D. P., Pandey, S. K., Wright, B. E., \& Moynihan, D. P. (2015). Public Service Motivation and Interpersonal Citizenship Behavior in Public Organizations : Testing a Prel

Park, S., \& Rainey, H.(2008). Leadership and public service motivation in U.S. Federal, agencies. International Public Management Journal, 11(1), 109-142.

Perry, J.(1996). Measuring public service motivation: An assessment of construct reliability and validity. Journal of Public Administration Research and Theory, 6(1), 5-22.

Perry, J.(1997). Antecedents of public service motivation. Journal of Public Administration Research and Theory, 7 (2), 181-197. https:// doi.org/10.2307/1181709

Perry, J.(2014). The motivational bases of public service: foundations for a third wave of research. Asia Pacific Journal of Public Administration, 36(1), 34-47. https:// doi.org/10.1080/23276665.2014.89227 2

Perry, J., Brudney, J., Coursey, D. H., \& Littlepage, L. (2008). What drives morally committed citizens? A study of the antecedents of public service motivation. Public Administration Review, 68(3), 445-458.

Perry, J., \& Hondeghem, A.(2008). Building theory and empirical evidence about public service motivation. International Public Management Journal, 11(1), 312.

Perry, J., Hondeghem, A., \& Wise, L.(2010). Revisiting the motivational bases of public service: twenty years of research and an agenda for the future. Public Administration Review, 70(5), 681-690. https://doi.org/10.1111/j.15406210.2010.02196.x

Perry, J., \& Wise, L.(1990). The motivational bases of public service. Public Administration Review, 50(3), 367-373. https:// doi.org/10.2307/976618

Prasetyaningsih. (2009). The Effect of Organizational Structure, Leadership, and Human Resource Capacity to the Certification Service of Land Rights Effectiveness at Land Office of Kendal Regency. Universitas Diponegoro.

Rainey, H.(1982). Reward preferences among public and private managers: in search of the public service ethic. American Review of Public Administration, 16(4), 288-302.

Rainey, H. ., \& Steinbauer, P.(1999). Galloping elephants: Developing elements of a theory of effective government organizations. Journal of Public Administration Research and Theory, 9(1), 1-32. https:// doi.org/10.1086/250095

Rianto, H., \& Firmansyah, S. (2017). Efforts 
Hety Budiyanti, Akhmat Yamin, Shine Pintor Siolemba Patiro - Public Service Motivation Measurement....

to Achieve Patriotism Values

Understanding In Students Studies

Program of PPKN IKIP PGRI

Pontianak. SOSIAL HORIZON: Social

Education Journal, 4(1), 86-96.

Schwab, D. P.(1980). Construct Validity in Organizational Behavior. Research in Organizational Behavior, 2(1), 3-43.

Skelcher, C., \& Smith, S.(2015). Theorising hybridity: institutional logics, complex organizations, and actor identities - the case of nonprofits. Public Administration, 93(2), 433-448. https:// doi.org/10.1111/padm.12105

Steijn, B. (2008). Person-environment fit and public service motivation. International Public Management Journal, 11(1), 13-27. https://doi.org/ Doi 10.1080/10967490801887863

Taylor, j.(2008). Organizational influence, public service motivation and work outcomes: An Australian study. International Public Management Journal, 11(1), 67-88. https:// doi.org/10.1080/10967490801887921

Vandenabeele, W.(2007). Towards a Theory of Public Service Motivation: An Institutional Approach. Public Management Review, 9(4), 545-556.

Vandenabeele, W.(2008). Development of a public service motivation measurement scale: Corroborating and extending Perry's measurement instrument. International Public Management Journal, 11(1), 143-167. https:// doi.org/10.1080/10967490801887970
Vandenabeele, W., Hondeghem, A., Maesschalck, J.,\& Depré, R.(2004). Values and motivation in public administration: Public service motivation in an international comparative perspective. In European Group of Public Administration Annual Conference,. Ljubljana, Slovenia. Retrieved from http:// search.ebscohost.com/login.aspx? direct $=$ true $\& d b=e d b \& A N=53606306 \&$ site $=$ eds-live $\&$ scope $=$ site

Vandenabeele, W., Ritz, A., \& Brewer, G. (2014). Past, present and future of public service motivation research. Public Administration, 92(4), 779-789. https://doi.org/Doi 10.1111/ Padm. 12136

Vandenabeele, W., \& van loon, N.(2015). Motivating employees using public service. In Handbook of Public Administration (Perry, J., pp. 353366). Jossey-Bass.

Wise, L. R.(2000). The Public Service Culture. In r. . I. Stillman (Ed.), Public Administration Concepts and Cases (7th ed., pp. 342-353). Boston: Hougnton Mifflin.

Wright, B., \& Pandey, S.(2008). Public service motivation and the assumption of person-organization fit: Testing the mediating effect of value congruence. Administration \& Society, 40(5), 502-521. https:// doi.org/10.1177/0095399708320187 